\title{
DNA Repair: Exploiting the Fanconi Anemia Pathway As a Potential Therapeutic Target
}

\author{
T. HUCL ${ }^{1}$, E. GALLMEIER ${ }^{2}$
}

${ }^{1}$ Department of Gastroenterology and Hepatology, Institute for Clinical and Experimental Medicine, Prague, Czech Republic, ${ }^{2}$ Department of Medicine II, University of Munich, Munich, Germany

Received November 15, 2010

Accepted January 21, 2011

On-line March 14, 2011

\section{Summary}

DNA repair is an active cellular process to respond to constant DNA damage caused by metabolic processes and environmental factors. Since the outcome of DNA damage is generally adverse and long term effects may contribute to oncogenesis, cells have developed a variety of DNA repair mechanisms, which operate depending on the type of DNA damage inflicted. At least 15 Fanconi anemia (FA) proteins interact in a common pathway involved in homologous recombination. Inherited homozygous mutations in any of these FA genes cause a rare disease, Fanconi anemia, characterized by congenital abnormalities, progressive bone-marrow failure and cancer susceptibility. Heterozygous germline FA mutations predispose to various types of cancer. In addition, somatic FA mutations have been identified in diverse cancer types. Evidence exists that cells deficient in the FA pathway become dependent on alternative pathways for survival. Additional inhibition of such alternative pathways is thus expected to result in cell death, creating a relationship of synthetic lethality. Identifying these relationships can reveal yet unknown mechanisms of DNA repair and new targets for therapy.

\section{Key words}

DNA damage • DNA repair • Fanconi anemia • Synthetic lethality

- Targeted therapy

\section{Corresponding author}

Tomas Hucl, Department of Gastroenterology and Hepatology, Institute for Clinical and Experimental Medicine, Videnska 9, 14021 Prague 4, Czech Republic. Fax: 00420261362615. E-mail: tomas.hucl@ikem.cz

\section{Introduction}

Owing to the ubiquitous DNA damage occurring to cells and thus to the critical importance of DNA repair in maintaining genome stability, there is a great natural interest in understanding the physiology and pathophysiology behind these processes. Due to the large variety of potential lesions, resulting from either endogenous or exogenous sources, no single repair process can efficiently repair all types of DNA damage. Instead, multiple DNA repair mechanisms have evolved to protect the cells vital genetic information.

DNA lesions involving single strands may be repaired by various mechanisms. Global genome NER (GG NER) repairs along the entire genome, whereas transcription-coupled repair (TCR) takes care of damage that blocks the RNA polymerase (Lodish 2000, Hoeijmakers 2001, Houtsmuller et al. 1999). Base excision repair (BER) is mostly directed towards repair of endogenous lesions due to cellular metabolism and is also activated by single strand breaks (SSB) (Lodish 2000, Barnes and Lindahl 2004). Mismatched but undamaged nucleotides resulting from replication are corrected by the mismatch repair (MMR) pathway (Lodish 2000, Harfe and Jinks-Robertson 2000). Translesion polymerases take over temporarily from the blocked replicative DNA polymerases, however their more flexible base-pairing properties leading to translesion synthesis (TLS) comes at the expense of a higher error rate (Lehmann 2006).

DNA double strand breaks (DSB) resulting mainly from ionizing radiation, $\mathrm{X}$-rays, free radicals and 
chemicals are solved by at least two pathways. Homologous recombination (HR) dominates in S and G2 phases, when DNA is replicated, providing a second copy of DNA for aligning, whereas non-homologous end joining (NHEJ) takes place mainly in the G1 phase of the cell cycle, when a second copy is not available.

Interestingly, almost identical processes to HR operate in chromosomal crossover during meiosis (Lodish 2000, Hoeijmakers 2001, Friedberg et al. 2006). Furthermore, NHEJ is required for joining DSB induced during $\mathrm{V}(\mathrm{D}) \mathrm{J}$ recombination in $\mathrm{B}$ and $\mathrm{T}$ cell receptors.

The choice which repair system to use depends both on the type of lesion and on the cell-cycle phase of the cell (Branzei and Foiani 2008). The cell-cycle machinery senses DNA damage and consecutively arrests at specific checkpoints in G1, S, G2 and M phases of the cell cycle to allow the repair of a lesion before its conversion into a permanent mutation. Irreparable DNA damage may be inflicted when DNA repair mechanisms fail and cellular mechanisms leading to apoptosis do not occur.

\section{DNA repair and cancer}

Cancer is a genetic disease (Vogelstein and Kinzler 2004). Over time, genes may accumulate changes, some of which activate proto-oncogenes, inactivate tumor-suppressor genes or alter DNA maintenance genes (Vogelstein and Kinzler 2004). The genetic instability driving tumorigenesis results in part from errors made by the DNA machinery. A variety of links have been identified between tumorigenesis and inherited or acquired alterations in DNA repair (Hoeijmakers 2001).

Inherited mutations in some DNA repair genes can predispose to cancer. Xeroderma pigmentosum is a disorder resulting from mutations in one of seven genes (XPA-XPG) involved in NER. Patients suffering from this disease exhibit an increased incidence of malignant tumors, particularly sun-induced skin cancer (Friedeberg et al. 2006).

Hereditary non-polypoid colorectal cancer (HNPCC) is an autosomal dominant disease caused mainly by mutations in the DNA mismatch repair genes MSH2 and MLH1, which lead to microsatellite instability. Patients have a high risk of developing colon cancer as well as endometrial, ovarian, hepatobiliary, stomach and other cancers. HNPCC is responsible for between 2 to $5 \%$ of colorectal cancers (Harfe and Jinks-Robertson
2000, Aaltonen et al. 1998).

Homologous recombination is altered in the following disorders; Ataxia teleangiectasia is caused by defects in the ATM kinase and is characterized by ataxia, teleangiectasias, immunodeficiency, chromosomal instability, ionizing radiation sensitivity and increased incidence of malignancies, primarily lymphomas and leukemia (Derheimer and Kastan 2010). Nijmegen breakage syndrome is caused by mutations in the NBS1 gene leading to microcephaly, growth retardation, radiation sensitivity and predisposition to malignancy. The $B L M$ gene, encoding a helicase, is mutated in Bloom syndrome. It is characterized by short stature, facial rash, immune deficiency and high cancer risk. Werner syndrome is caused by mutations in the WRN gene leading to telomere instability and is characterized by premature aging and development of various cancers (Friedeberg et al. 2006).

Inherited mutations in $B R C A 1 / B R C A 2$ are responsible for the majority of familial ovarian and breast cancers (King et al. 2003). Furthermore, subjects with $B R C A 1 / 2$ mutations have an increased risk of developing other cancers including pancreatic, prostate, stomach, gall-bladder or colon cancer (Friedenson 2005). Fanconi anemia (FA) is another disease with altered homologous recombination predisposing to cancer.

Somatic mutations in DNA repair genes have been reported in sporadic tumors (D'Andrea 2010). Apart from the inherited and somatic mutations, it may be assumed that the individual genetic background modulating the DNA repair capacity, such as that resulting from functional polymorphisms in DNA repair genes, may affect the susceptibility to cancer (Naccarati et al. 2007).

\section{Fanconi anemia}

FA is an autosomal or $\mathrm{x}$-chromosomal recessive disease with a prevalence of one to five cases per million. Most patients are diagnosed before the age of 10 years and the median age at death is around 30 years. The disease is caused by biallelic mutations in one of at least 15 FA genes and is characterized by congenital growth abnormalities, bone marrow failure and cancer predisposition. Congenital abnormalities include short stature and skin, extremity, head, kidney, ears or eyes abnormalities. Bone marrow failure causes pancytopenia and develops in $90 \%$ of patients by the age of 40 years. Malignancies develop in about a quarter of patients and 


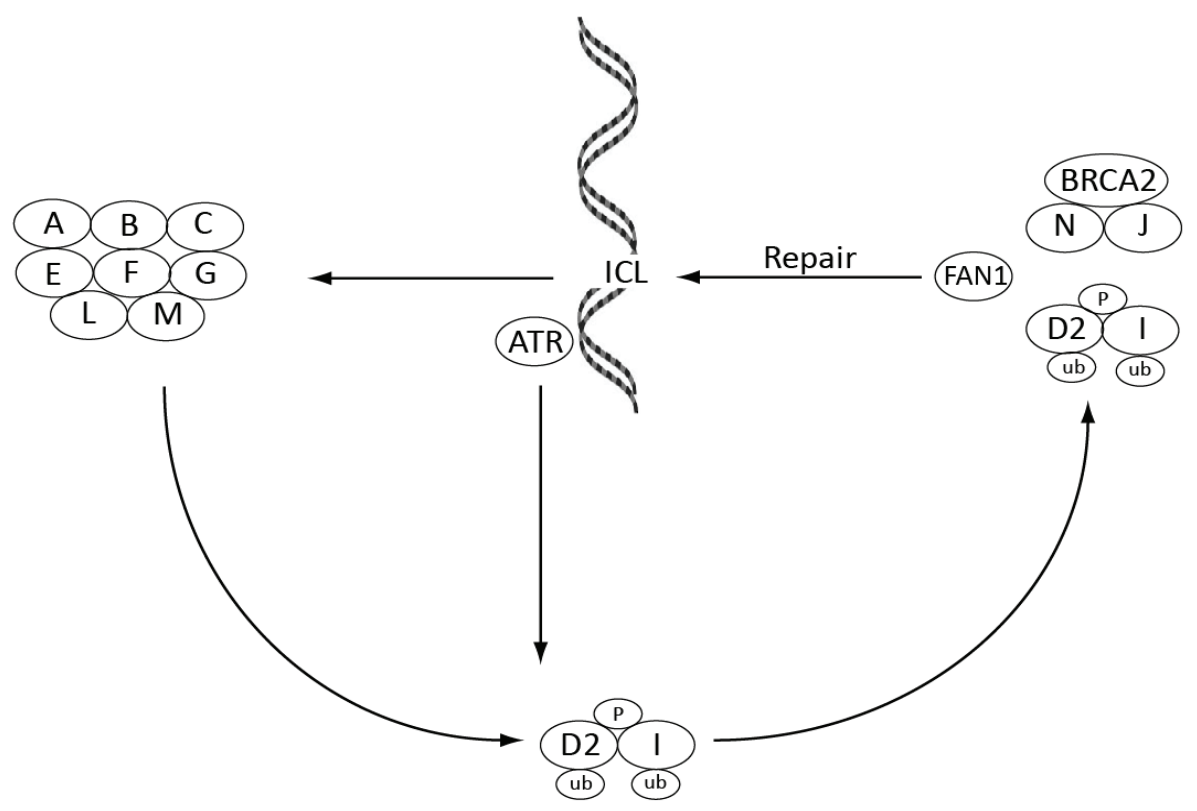

Fig. 1. The Fanconi anemia DNA repair pathway. Following DNA damage, the ATR kinase activates the FA core complex consisting of 8 proteins (FANCA, B, C, E, F, G, L, $M)$ and phosphorylates FANCD2/ FANCI. The core complex then monoubiquitinates FANCD2/FANCI, which is targeted to the site of DNA damage where it forms a complex with other FA proteins (BRCA2, FANCN, FANCJ), FA-associated proteins (FAN1) or other proteins to repair DNA.

include acute myelogenous leukemia, squamous-cell carcinoma of the head and neck, esophageal carcinoma, liver, brain, skin, kidney and gynecologic cancers (Alter 1996, Xie et al. 2000, D'Andrea and Grompe 2003).

It still remains speculative how a defect of a single DNA repair gene can lead to developmental abnormalities, bone marrow failure and cancer predisposition. Conceivably however, a DNA repair defect may, on one hand, lead to accumulation of DNA damage and chromosomal instability causing cancer predisposition and, on the other hand, induce apoptosis resulting in the depletion of hematopoietic stem cells (Moldovan and D'Andrea 2009).

A typical cellular feature of FA cells is a specific hypersensitivity towards DNA interstrand cross-linking agents, such as mitomycin $\mathrm{C}$, cisplatin or diepoxybutane (DEB) (D'Andrea and Grompe 2003). The robustness of this phenomenon even facilitates a functional diagnostic test for FA (the DEB-induced chromosome-breakage test), which is based on the particular ICLhypersensitivity of lymphocytes as functional read-out (Auerbach 1993). From the physician's point of view, general standards of care for FA patients include the application of hematopoietic growth factors, androgen therapy, as well as bone-marrow transplantation, preimplantation genetic diagnosis and prevention, surveillance, and importantly, the early detection and treatment of malignancies (Guinan et al. 1994). However, due to the FA DNA repair defect, radiotherapy and chemotherapy have increased toxic side effects in patients with FA as compared to the general population and, if these agents are applied, dosage reduction is strongly recommended (Alter et al. 2002, Taniguchi et al. 2006, Hosoya et al. 2010).

\section{The Fanconi anemia pathway}

Initially, cell-fusion experiments have proven the existence of multiple separate FA complementation groups. Later, functional complementation of ICLsensitive cells with cDNA, positional cloning or direct sequencing resulted in identification of the corresponding genes (D'Andrea and Grompe 2003). A better understanding of the FA pathway was facilitated through the discovery of biallelic mutations in the breast cancer gene $B R C A 2$ in patients classified as Fanconi anemia complementation group D1 (Howlett et al. 2002). There are at least 15 genes involved in FA, which are dispersed throughout the genome (D'Andrea 2010). Complementation groups $\mathrm{A}, \mathrm{C}$ and $\mathrm{G}$ represent around $90 \%$ of FA patients (FANCA $70 \%$, FANCC $10 \%$, FANCG 10\%) (Moldovan and D'Andrea 2009). Mutations in RAD51C (FANCO), involved in HR, have recently been found in a family with multiple congenital abnormalities characteristic of FA (Vaz et al. 2010). Furthermore, biallelic mutations in SLX4 (FANCP), an important component of the BRCA-FA pathway, have recently been identified in patients with FA (Stoepker et al. 2011).

The proteins encoded by the FA genes presumably cooperate in a common DNA repair pathway to recognize and repair DNA damage (Figure 1). Upon 
entry into the $\mathrm{S}$ phase of the cell cycle or upon DNA damage, the eight upstream FA proteins assemble into a ubiquitin ligase complex (A,B,C,E,F,G,L, M and N) that monubiquitinates FANCD2 and FANCI. Consequently, the ubiquitinated FANCD2/FANCI complex is directed to the nucleus where it binds to chromatin and recruits the downstream FA proteins (D1, N, J) and additional DNA repair proteins such as BRCA1. These downstream members participate in DNA repair by homologous recombination (Moldovan and D'Andrea 2009, Knipscheer et al. 2009). FANCD1/BRCA2 is specifically involved in homologous recombination, mediated by its interaction with RAD51 (Hucl et al. 2008). A novel protein, FAN1 has recently been identified to cooperate with FANCD2 in ICL repair (Liu et al. 2010).

A new and interesting role of the FA pathway in controlling mutation rates through translesion synthesis (TLS) has recently been revealed. Surprisingly, cells defective in the upstream core complex show a reduced rate of point mutations introduced by TLS, suggesting a requirement of the core complex for the TLS pathway. However, loss of the downstream FANCD2/FANCI complex leads to a significant increase in the mutation rate and upregulation of TLS (Mirchandani et al. 2008). This upregulation may perhaps make cells defective in the downstream part of the FA pathway dependant on TLS.

In addition, phosphorylation of FA proteins through the action of ATR and ATM appears to be another critical step for activation of the FA pathway. The ATR kinase coordinates the cellular response upon DNA damage. In addition to its main effector gene CHK1, ATR also phosphorylates several components of the FA pathway with the main targets being FANCD2 and FANCI (Ishiai et al. 2008). ATR-dependent phosphorylation of FANCI induces FANCD2 monoubiquitination and DNA repair (Moldovan and D'Andrea 2009, Kennedy et al. 2007, Friedel et al. 2009). Consequently, Seckel syndrome, which is caused by a hypomorphic splice-site mutation $(2101 \mathrm{~A}->\mathrm{G})$ in the ATR gene that leads to a subtotal depletion of ATR protein (O’Driscoll et al. 2003), displays a cellular phenotype similar to that of FA cells (Andreassen et al. 2004).

\section{Fanconi anemia mutations and solid cancers}

Biallelic germline mutations in FA genes occur in patients with FA, but heterozygous germline mutations, somatic mutations and epigenetic silencing also occur in cancer patients among the general population (non-FA patients) (Marsit et al. 2004, Pejovic et al. 2006, Dhillon et al. 2004, Narayan et al. 2004, Taniguchi and D'Andrea 2006, Goggins et al. 1996, Condie et al. 2002).

Biallelic mutations of BRCA2/FANCD1 gene result in a severe form of FA. Heterozygote carriers of $B R C A 2 / F A N C D 1$ gene mutations have an increased risk of breast and ovarian cancer (King et al. 2003). The tumors develop as a result of loss of the wild-type allele. Surprisingly, Skoulidis et al. have recently reported that loss of the wild-type allele in BRCA2 mutation carriers may not be essential for pancreatic ductal carcinogenesis. In their Kras-driven murine model, heterozygosity of $B R C A 2$ promoted carcinogenesis but a significant proportion of developed tumors retained a functional allele (Skoulidis et al. 2010). In support of these at first sight counterintuitive findings, we previously reported that complete (bi-allelic) inactivation of the BRCA2 gene might in most instances be a detrimental event for cancer cells, establishing the paradoxical assumption that despite an apparent selection for FA pathway inactivation in cancer, BRCA2 inactivation might be predominantly selected against in cancer cells (Gallmeier et al. 2007b).

The causes of tissue specificity of cancer predisposition remain unclear. Estrogen may promote survival of breast and ovarian cells acquiring loss of the wild type allele, whereas cells acquiring the same loss without the influence of estrogen undergo apoptosis. In this respect, oophorectomy may provide protection from cancer in $B R C A 2$ mutation carriers. Interestingly, FA patients, characterized by hypogonadism, rarely develop breast or ovarian cancer (Elledge and Amon 2002). Another example of tissue specificity is the development of liver tumors in FA patients. The development of liver tumors has been strongly associated with androgen therapy, which is often used in treatment of bone marrow failure of FA patients. Of note, we have recently reported disruption of the FA pathway in hepatocelular cancer (HCC) through an inactivating mutation in FANCC. Thus, the association of FA with HCC could be attributable not only to potential secondary, amplifying or accelerating effets o androgen therapy in FA patients, but likely also to potential primary tumorigenic effects of FA pathway inactivation in hepatocytes (Valazquez et al. 2004, Palagyi et al. 2010).

Heterozygous BRCA2 mutations predispose patients to pancreatic cancer (Goggins et al. 1996, 
Murphy et al. 2002). Hahn et al. reported BRCA2 mutations in almost $20 \%$ of families with familial pancreatic cancer in Europe (Hahn et al. 2003). The discovery that $F A N C D 1$ is identical to $B R C A 2$ resulted in a search for mutations in other FA genes as possible pancreatic-cancer risk genes, which resulted in identification of somatic and germline mutations in $F A N C C$ and FANCG in patients with pancreatic cancer (van der Heijden et al. 2003, Couch et al. 2005). The later identification of BRIP1/BACH1 (FANCJ) and PALB2 (FANCN) as new FA pathway genes (Levitus et al. 2005, Xia et al. 2007, Reid et al. 2007) resulted in their close examination as new breast, ovarian and pancreatic cancer risk genes. Both genes have meanwhile been identified as breast cancer and the latter as breast and pancreatic cancer susceptibility genes (Cantor et al. 2004, Seal et al. 2006, Rahman et al. 2007, Jones et al. 2009, Tischkowitz et al. 2009).

In addition, a screen of a panel of GI cancers recently identified a $F A N C C$ mutation in a hepatocellular carcinoma cell line, adding another tumor entity to the list of solid cancers harboring FA gene mutations (Palagyi et al. 2010). Furthermore, epigenetic inactivation via promoter hypermethylation of $F A N C F$ has been reported in a variety of cancers, such as ovarian, cervical, bladder, lung and oral cancers, though its importance remains to be determined (Dhillon et al. 2004, Narayan et al. 2004).

\section{Models to study the Fanconi anemia pathway}

Several cancer-related genes are associated with specific types of cancer despite their ubiquitous function. Furthermore, there are examples of different phenotypes observed following gene inactivation in different species. Thus, the context with respect to cell-type, species and model used, is important, suggesting that experimental results and relationships discovered in the laboratory need to be validated in the respective relevant human cell subsets (Gallmeier and Kern 2007).

Various models of FA gene defects have been developed. Models utilizing different species (human, mouse, hamster, chicken, frog and zebrafish), malignant or nonmalignant cells, natural selection or artificial engineering, isogenic or nonisogenic cells, gene overexpression, targeted or nonspecific gene knockout or knockin or RNA interference have been used. Each model has certain limitations. In general, models in which FA gene defects are artificially created or corrected might not accurately reflect the phenotype of this defect in a natural setting. Thus, the extent to which findings in these preclinical models can be translated to humans, needs to be fully assessed and caution needs to be exercised when extrapolating cell-culture results to humans (Gallmeier and Kern 2007).

\section{Targeting DNA repair defects in cancer}

Most anticancer drugs inhibit mitosis or DNA replication, thus killing rapidly dividing cells. However, when administered to patients, many will also injure rapidly dividing normal cells. Therapeutic index, the difference between the dose that gives a therapeutic effect and the dose that gives unacceptable toxicity, is often small. The aim of targeted therapy is to apply our increased understanding of the molecular signature of a tumor to develop drugs that exert a high efficiency only in targeted tumor cells, while exerting minimal toxicity in wild-type cells, thus enlarging the therapeutic window (Hucl et al. 2007).

Disruption of the FA pathway leads to defective DNA repair causing genomic instability and cancer progression. On the other hand, the cells gain a tumorspecific absolute biochemical difference (Hahn et al. 1996). This difference between DNA repair-proficient normal cells and DNA repair-deficient cancer cells can be exploited therapeutically in at least two ways. First, the deficient cells may be more sensitive to agents that induce lesions normally repaired by the respective pathway. Secondly, synthetic lethality, in which gene inhibition is cytotoxic only in the presence of an additional mutation in a different (compensating) pathway, may be exploited to find new treatment targets and discover new mechanisms of DNA repair.

Cells defective in the proximal FA pathway are hypersensitive to certain therapeutics, particularly ICL agents. The extent of hypersensitivity depends on the specific ICL agent used and seems to reflect the proportional contribution of ICLs to the overall toxicity of the drug (van der Heijden et al. 2004, Gallmeier et al. 2006). Cells defective in the distal part of the pathway, namely in homologous recombination, are hypersensitive to ICL agents, etoposide and irradiation (Hucl et al. 2008). Increased sensitivity to some of these drugs may be responsible for better survival of FA-deficient tumors (Engelstaedter et al. 2010).

Irradiation sensitivity of FA cells remains controversial due to very different results ranging from strong hypersensitivity to no changes depending on the 
model used (Gallmeier et al. 2006, Hucl et al. 2008, Kalb et al. 2004). Increased radiation sensitivity would be of particular interest in the treatment of pancreatic cancer, especially as the issue of radiation sensitivity of pancreatic cancer is still controversially discussed. (Hazard 2009).

Identification of novel agents to which FA pathway-deficient cells are hypersensitive could provide additional therapeutic opportunities and also contribute to a better understanding of the biochemical mechanisms that underlie the FA-related chemical hypersensitivity phenotype. The discovery of new agents that confer increased sensitivity via different mechanisms might also be useful for the development of combination therapies that produce synergistic effects and decrease the risk of resistance development (Gallmeier et al. 2007a).

\section{Synthetic lethality}

Two genes are synthetic lethal if a mutation in either gene alone is lethal only in the presence of a mutation in the other gene. Inhibition of genes that are synthetic lethal to cancer-causing mutations should then be lethal for cells that harbor such mutations but not for surrounding normal cells (Kaelin 2005). Such a relationship may arise for example from genes being redundant with respect to an essential function or genes that participate in an essential linear or parallel pathway.

Protein products of genes synthetic lethal to known cancer mutations represent innovative and excellent targets for anticancer treatment (Hartwell et al. 1997). Their identification is challenging since the relationship is not always intuitive. Screens for synthetic lethality are carried out using either libraries of chemical compounds or genetic tools such as RNAi. First chemical screens done in yeast deletion mutants defective in DNA repair were followed by detailed exploration of gene-gene interactions using yeast double mutants (Simon et al. 1997). In mammalian cells, K-ras mutated cells and their isogenic controls were used in the first chemical screens (Torrance et al. 2001). However, successful target identification as well as the generability of virtually infinite numbers of diverse chemical compounds in vast libraries may remain a problem of chemical screens.

We previously conducted a chemical screen with 880 active drugs and 40,000 diverse compounds in isogenic cells defective in FANCC and FANCG. Several compounds eliciting hypersensitivity in FA pathwaydeficient cells were identified. One compound with the strongest effect acted via a different mechanism than ICL agents, not causing FANCD2 monoubiquitination or ICL induction. When the agent was combined with ICL agents, additive and potentially even synergistic toxic effects were observed, supporting a combinational use to enhance the known therapeutic window of ICL agents in FA-deficient cells (Gallmeier et al. 2007a).

Genetic screens typically involve RNAi (Willingham et al. 2004). Early studies in yeast, fruit flies and worms have been followed by high-throughput genome-wide screens in human cells since large collections of interfering RNAs have been available (van Haaften et al. 2004). To this end, molecules of short interfering RNA (siRNA) or short hairpin RNAs (shRNA) encoded by plasmid or viral vectors are commonly used (Kaelin 2005).

Two possible synthetic lethality interactions in downstream FA pathway genes can be envisioned. First, there might be functional redundancy in DNA repair. Thus, when a certain lesion cannot be repaired by one pathway, another pathway may take over. Even though there may be consequences of such an alternative repair such as lower efficiency or lower accuracy, cells may become dependent on this alternative pathway to survive. Second, if the FA pathway serves as a backup for another pathway repairing another type of lesion, inhibition of such a pathway will lead to the requirement of the FA pathway and thus be detrimental in FA pathway-deficient cells (Evers et al. 2010).

Partial functional redundancy and cooperation of multiple pathways in repair of a particular lesion is illustrated by that fact that ICL repair involves at least three pathways, NER, TLS and HR (de Silva et al. 2000, Zheng et al. 2003, Rothfuss et al. 2004). Similarly, DSBs repair involves HR, its variant SSA and NHEJ (Lodish 2000). Consequently, a defect in one pathway mechanism may lead to utilization, upregulation or even dependence on another pathway (Figure 2). Cells defective in the FA pathway have been shown to have elevated NHEJ, SSA or TLS, suggesting possible candidates for synthetic lethality (Tutt et al. 2001). Apart from these known alternative pathways, there may be yet unknown mechanisms of backup repair. In yeast, for example, a minor pathway involved in ICL repair has been described. This pathway involves Pso2 nuclease and may also be hyperactive in FA deficient human cells (Barber et al. 2001).

An example of the second type of synthetic lethality interaction in HR-deficient cells is the 


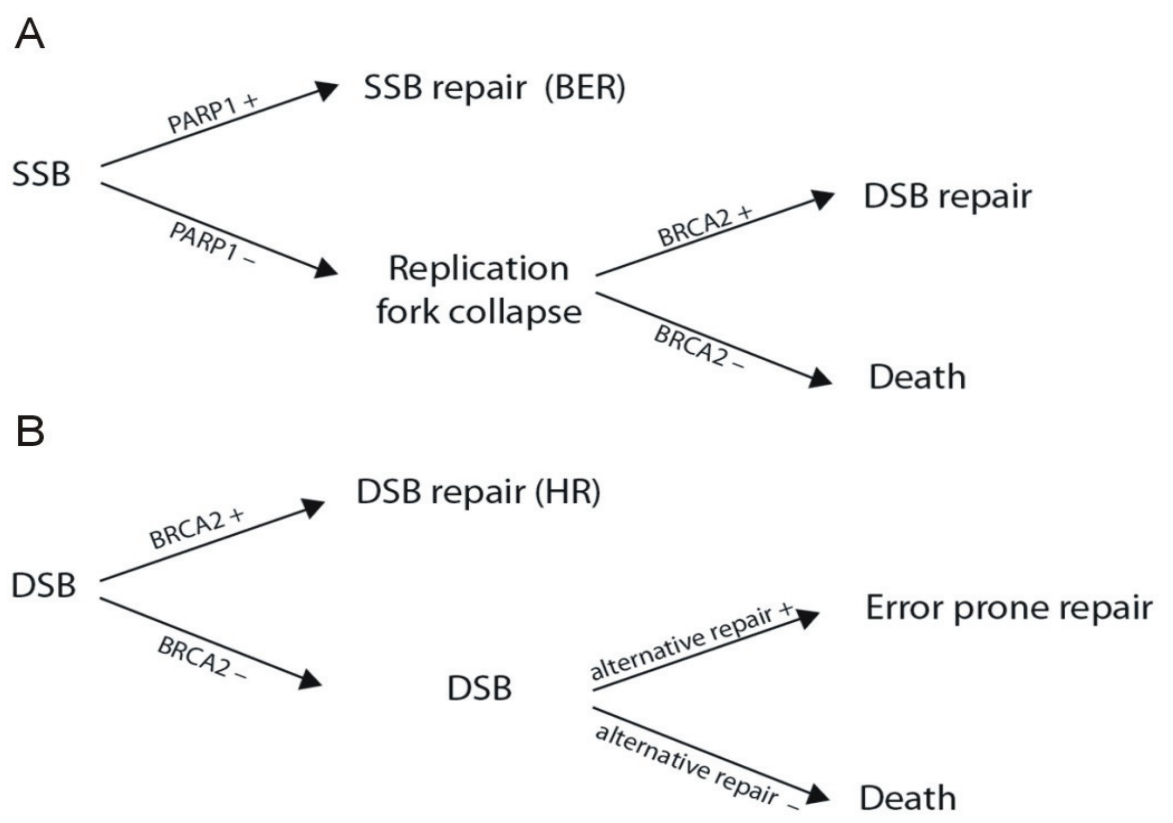

Fig. 2. Synthetic lethality relationships in HR-deficient cells. A model of two different synthetic lethality relationships in BRCA2-deficient cells. A. Upon SSB, PARP1 proficient cells will repair the defect using BER. In case of PARP1 deficiency, SSB will result in replication fork collapse requiring $\mathrm{HR}$ for repair. In $B R C A 2$-proficient cells, HR recombination will be used, whereas $B R C A 2$ deficiency will result in death. B. Upon DSB, BRCA2-proficient cells will utilize HR for repair. BRCA2deficient cells will turn to alternative error prone mechanisms of repair. Absence/inhibition of this alternative repair will result in death selectively in BRCA2-deficient cells. relationship between poly (ADP-ribose) polymerase-1 (PARP-1) and BRCA2 (Figure 2). PARP-1 is involved in base excision repair, a pathway repairing DNA singlestrand breaks (SSB). In case of PARP-1 deficiency, endogenously occurring SSBs cannot be repaired and result in replication fork collapse and DSBs. HR-deficient cells are unable of DSB resolution, resulting in chromosomal instability, cell cycle arrest and cell death. PARP-1 activity is thus essential in HR-deficient cells. Since there are about $10^{4}$ spontaneous SSBs per cell per day, inhibition of PARP-1 alone gives a chance to selectively kill a tumor in the absence of an exogenous DNA-damaging agent. Bryant et al. and Farmer et al. showed that PARP-1 treatment inhibited the growth or killed BRCA2-deficient xenograft tumors in mice (Bryant et al. 2005, Farmer et al. 2005). Clinical trials with a PARP-1 inhibitor in patients with BRCA2-deficient ovarian cancer have been initiated (Audeh et al. 2010). Combinations of PARP-1 inhibitors with DNA damaging agents have also been used experimentally with promising results (Evers et al. 2008). Furthermore, improved responsiveness to platinum and PARP1 inhibitors have also been observed in sporadic cancers with gene expression profile based BRCAness (Konstantinopoulos et al. 2010).

As a result of a large siRNA screen covering 230 specific DNA damage response genes in FANCG deficient cells, a synthetic lethality relationship between FANCG and ATM was established (Kennedy et al. 2007). FA pathway-deficient cells displayed constitutive activation of ATM and consecutive inhibition of ATM resulted in DNA breakage, cell cycle arrest and cell death. Using an ATM inhibitor, selective toxicity of FANCC and FANCG-deficient pancreatic cancer cells lines was observed (Kennedy et al. 2007).

Apart from performing a large genetic screen using RNAi, a cross species candidate gene approach may be applied. Synthetic lethality relationship observed in yeast is recapitulated in human cells. Synthetic lethal interaction observed in double mutant RAD54 and RAD27 yeast cells was confirmed between human homologs RAD54B and FEN1. Consistently, RAD54B-deficient human colorectal cancer cells were selectively sensitive to FEN1 inhibition (McManus et al. 2009).

\section{Fanconi anemia pathway inactivation as a predictive biomarker of chemotherapeutic response}

The use of targeted therapy against FA pathwaydeficient tumors requires their identification. FA pathway biomarkers may be direct and measure the availability of the pathway without the need of prior DNA damage exposure. Direct sequencing of known genes is possible but technically and financially demanding. Other possibilities include gene/protein expression or promoter methylation studies. However, mutated genes may produce normal levels of mRNA or protein. Functional studies, such as monoubiquitination of FANCD2 or RAD51 focus formation test the integrity of the pathway 
without needing to know the identity of the defect, however they require exposure of tissue to DNA damage prior to testing (Kennedy and D'Andrea 2006). Development of easy and reproducible methods that could be widely adopted has proven very cumbersome. Recent successful application of HR status determination using RAD51 focus formation in primary cell cultures may prove useful not only to identify HR-deficient cells but also to test their in vitro chemosensitivity (Mukhopadhyay et al. 2010).

\section{Summary}

There is various endogenous and exogenous DNA damage continuously occurring in cells. Disruption of DNA repair results in an increased rate of mutagenesis and is associated with cancer development, but it also renders cells susceptible to DNA damage following exposure to exogenous DNA-damaging agents. Their use or pharmaceutical inhibition of genes that are synthetic lethal with cancer-causing mutations in DNA repair genes may soon play a significant role in the treatment of FA pathway-deficient human cancers.

\section{Conflict of Interest}

There is no conflict of interest.

\section{Acknowledgements}

The authors were supported by grants to TH (GAAV KJB 502030901) and EG (DFG Ga762/3-1, Bavarian Academy of Sciences and Arts, Förderprogramm für Forschung und Lehre, K.L. Weigand Fund).

\section{References}

AALTONEN LA, SALOVAARA R, KRISTO P, CANZIAN F, HEMMINKI A, PELTOMAKI P, CHADWICK RB, KAARIAINEN H, ESKELINEN M, JARVINEN H, MECKLIN JP, DE LA CHAPELLE A: Incidence of hereditary nonpolyposis colorectal cancer and the feasibility of molecular screening for the disease. $N$ Engl $J$ Med 338: 1481-1487, 1998.

ALTER BP: Fanconi's anemia and malignancies. Am J Hematol 53: 99-110, 1996.

ALTER BP: Radiosensitivity in Fanconi’s anemia patients. Radiother Oncol 62: 345-347, 2002.

ANDREASSEN PR, D'ANDREA AD, TANIGUCHI T: ATR couples FANCD2 monoubiquitination to the DNAdamage response. Genes Dev 18: 1958-1963, 2004.

AUDEH MW, CARMICHAEL J, PENSON RT, FRIEDLANDER M, POWELL B, BELL-MCGUINN KM, SCOTT C, WEITZEL JN, OAKNIN A, LOMAN N, LU K, SCHMUTZLER RK, MATULONIS U, WICKENS M, TUTT A: Oral poly(ADP ribose) polymerase inhibitor olaparib in patients with BRCA1 or BRCA2 mutations and recurrent ovarian cancer: a proof-of-concept trial. Lancet 376: 245-251, 2010.

AUERBACH AD: Fanconi anemia diagnosis and the diepoxybutane (DEB) test. Exp Hematol 21: 731-733, 1993.

BARBER LJ, WARD TA, HARTLEY JA, MCHUGH PJ: DNA interstrand cross-link repair in the Saccharomyces cerevisiae cell cycle: overlapping roles for PSO2 (SNM1) with MutS factors and EXO1 during S phase. Mol Cell Biol 25: 2297-2309, 2005.

BARNES DE, LINDAHL T: Repair and genetic consequences of endogenous DNA base damage in mammalian cells. Annu Rev Genet 38: 445-476, 2004.

BEN DAVID Y, CHETRIT A, HIRSH-YECHEZKEL G, FRIEDMAN E, BECK BD, BELLER U, BEN-BARUCH G, FISHMAN A, LEVAVI H, LUBIN F, MENCZER J, PIURA B, STRUEWING JP, MODAN B; NATIONAL ISRAELI STUDY OF OVARIAN CANCER: Effect of BRCA mutations on the length of survival in epithelial ovarian tumors. J Clin Oncol 20: 463-466, 2002.

BRANZEI D, FOIANI M: Regulation of DNA repair throughout the cell cycle. Nat Rev Mol Cell Biol 9: 297-308, 2008.

BRYANT HE, SCHULTZ N, THOMAS HD, PARKER KM, FLOWER D, LOPEZ E, KYLE S, MEUTH M, CURTIN NJ, HELLEDAY T: Specific killing of BRCA2-deficient tumourswith inhibitors of poly(ADP-ribose) polymerase. Nature 434: 913-916, 2005.

CANTOR S, DRAPKIN R, ZHANG F, LIN Y, HAN J, PAMIDI S, LIVINGSTONE DM: The BRCA1-associated protein BACH1 is a DNA helicase targeted by clinically relevant inactivating mutations. Proc Natl Acad Sci U S A 101: 2357-2362, 2004. 
CONDIE A, POWLES RL, HUDSON CD, SHEPHERD V, BEVAN S, YUILLE MR, HOULSTON RS: Analysis of the Fanconi anaemia complementation group A gene in acute myeoloid leukaemia. Leuk Lymphoma 43: 1849$1853,2002$.

COUCH FJ, JOHNSON MR, RABE K, BOARDMAN L, MCWILLIAMS R, DE ANDRADE M, PETERSEN G: Germ line Fanconi anemia complementation group $\mathrm{C}$ mutations and pancreatic cancer. Cancer Res 65: 383-386, 2005.

D'ANDREA AD, GROMPE M: The Fanconi anaemia/BRCA pathway. Nat Rev Cancer 3: 23-34, 2003.

D'ANDREA AD: Susceptibility pathways in Fanconi's anemia and breast cancer. N Engl J Med 362: 1909-1919, 2010.

DE SILVA IU, MCHUGH PJ, CLINGEN PH, HARTLEY JA: Defining the roles of nucleotide excision repair and recombination in the repair of DNA interstand cross-links in mammalian cells. Mol Cell Biol 20: 7980-7990, 2000.

DERHEIMER FA, KASTAN MB: Multiple roles of ATM in monitoring and maintaining DNA intergrity. FEBS Lett 584: 3675-3681, 2010.

DHILLON VS, SHAHID M, HUSAIN SA: CpG methylation of the FHIT, FANCF, cyclin-D2, BRCA2 and RUNX3 genes in Granulosa cell tumors (GCTs) of ovarian origin. Mol Cancer 3: 33, 2004.

ELLEDGE SJ, AMON A: The BRCA1 suppressor hypothesis: an explanation for the tissue-specific tumor development in BRCA1 patients. Cancer Cell 1: 129-132, 2002.

ENGELSTAEDTER V, CRISTEA MC, GARBER JE, NEUHAUSEN SL, FRANKEL PH, SAND S, STEELE L, MATULONIS U, LIU J, WEITZEL J: Clinical characteristics and outcomes of BRCA-associated ovarian cancer (OC): Genotype and survival. J Clin Oncol 28: 15s, 2010.

EVERS B, DROST R, SCHUT E, DE BRUIN M, VAN DER BURG E, DERKSEN PW, HOLSTEGE H, LIU X, VAN DRUNEN E, BEVERLOO HB, SMITH GC, MARTIN NM, LAU A, O'CONNOR MJ, JONKERS J: Selective inhibition of BRCA2-deficient mammary tumor cell growth by AZD2281 and cisplatin. Clin Cancer Res 14: 3916-3925, 2008.

EVERS B, HELLEDAY T, JONKER J: Targeting homologous recombination repair defects in cancer. Trends Pharmacol Sci 31: 372-380, 2010.

FARMER H, MCCABE N, LORD CJ, TUTT ANJ, JOHNSON DA, RICHARDSON TB, SANTAROSA M, DILLON KJ, HICKSON I, KNIGHTS C, MARTIN NMB, JACKSON SP, SMITH GCM, ASHWORT A: Targeting the DNA repair defect in BRCA mutant cells as a therapeutic strategy. Nature 434: 917-921, 2005.

FRIEDEL AM, PIKE BL, GASSER SM: ATR/Mec1: coordinating fork stability and repair. Curr Opin Cell Bio 21: 237-244, 2009.

FRIEDENSON B: BRCA1 and BRCA2 pathways and the risk o cancers other than breast or ovarian. MedGenMed 7: 60, 2005.

FRIEDBERG EC, AGUILERA A, GELLERT M, HANAWALT PC, HAYS JB, LEHMANN AR, LINDAHL T, LOWNDES N, SARASIN A, WOOD RD: DNA repair: from molecular mechanisms to human disease. DNA Repair (Amst) 5: 986-996, 2006.

GALLMEIER E, CALHOUN ES, RAGO C, BRODY JR, CUNNINGHAM SC, HUCL T, GOROSPE M, KOHLI M, LENGAUER C, KERN SE: Targeted disruption of FANCC and FANCG in human cancer provides a preclinical model for specific therapeutic options. Gastroenterology 130: 2145-2154, 2006.

GALLMEIER E, HUCL T, BRODY JR, DEZENTJE DA, TAHIR K, KASPARKOVA J, BRABEC V, BACHMAN KE, KERN SE: High-throughput screening identifies novel agents eliciting hypersensitivity in Fanconi pathway-deficient cancer cells. Cancer Res 67: 2169-2177, 2007a.

GALLMEIER E, KERN SE: Absence of specific cell killing of the BRCA2-deficient human cancer cell line CAPAN1 by poly(ADP-ribose) polymerase inhibition. Cancer Biol Ther 4: 703-706, 2005.

GALLMEIER E, HUCL T, CALHOUN ES, CUNNINGHAM SC, BUNZ F, BRODY JR, KERN SE: Gene-specific selection against experimental fanconi anemia gene inactivation in human cancer. Cancer Biol Ther 6: 654$660,2007 b$.

GALLMEIER E, KERN SE: Targeting fanconi anemia/BRCA2 pathway defects in cancer: the significance of preclinical pharmacogenomic models. Clin Cancer Res 13: 4-9, 2007. 
GOGGINS M, SCHUTTE M, LU J, MOSKALUK CA, WEINSTEIN CL, PETERSEN GM, YEO CJ, JACKSON CE, LYNCH HT, HRUBAN RH, KERN SE: Germline BRCA2ge ne mutations in patients with apparently sporadic pancreatic carcinomas. Cancer Res 56: 5360-5364, 1996.

GUINAN EC, LOPEZ KD, HUHN RD, FELSER JM, NATHAN DG: Evaluation of granulocyte-macrophage colonystimulating factor for treatment of pancytopenia in children with fanconi anemia. J Pediatr 14: 144-150, 1994.

HAHN SA, SCHUTTE M, HOQUE AT, MOSKALUK CA, DA COSTA LT, ROZENBLUM E, WEINSTEIN CL, FISCHER A, YEO CJ, HRUBAN RH, KERN SE: DPC4, a candidate tumor suppressor gene at human chromosome 18q21.1. Science 271: 350-353, 1996.

HAHN SA, GREENHALF B, ELLIS I, SINA-FREY M, RIEDER H, KORTE B, GERDES B, KRESS R, ZIEGLER A, RAEBURN JA, CAMPRA D, GRUTZMANN R, REHDER H, ROTHMUND M, SCHMIEGEL W, NEOPTOLEMOS JP, BARTSCH DK: BRCA2 germline mutations in familial pancreatic carcinoma. $J$ Natl Cancer Inst 95: 214-221, 2003.

HARFE BD, JINKS-ROBERTSON S: DNA mismatch repair and genetic instability. Annu Rev Genet 34: 359-399, 2000.

HARTWELL L, SZANKASI P, ROBERTS C, MURRAY A, FRIEND S: Integrating genetic approaches into the discovery of anticancer drugs. Science 278: 1064-1068, 1997.

HAZARD L: The role of radiation therapy in pancreas cancer. Gastrointest Cancer Res 3: 20-28, 2009.

HELLEDAY T, LO J, VAN GENT DC, ENGELWARD BP: DNA double-strand break repair: from mechanistic understanding to cancer treatment. DNA Repair (Amst) 6: 923-935, 2007.

HOEIJMAKERS JHJ: Genome maintenance mechanisms for preventing cancer. Nature 411: 366-374, 2001.

HOSOYA Y, LEFOR Y, HIRASHIMA Y, NOKUBI M, YAMAGUTI T, JINBU Y, MUROI K, NAKAZAWA M, YASUDA Y: Successful treatment of esophageal squamous cell carcinoma in a patient with Fanconi anemia. Jpn J Clin Oncol 40: 805-810, 2010.

HOUTSMULLER AB, RADEMAKERS S, NIGG AL, HOOGSTRATEN D, HOEIJMAKERS JH, VERMEULEN W: Action of DNA repair endonuclease ERCC1/XPF in living cells. Science 284: 958-961, 1999.

HOWLETT NG, TANIGUCHI T, OLSON S, COX B, WAISFISZ Q, DE DIE-SMULDERS C, PERSKY N, GROMPE M, JOENJE H, PALS G, IKEDA H, FOX EA, D'ANDREA AD: Biallelic inactivation of BRCA2 in Fanconi anemia. Science 297: 606-609, 2002.

HUCL T, RAGO C, GALLMEIER E, BRODY JR, GOROSPE M, KERN SE: A syngeneic variance library for functional annotation of human variation: application to BRCA2. Cancer Res 68: 5023-5030, 2008.

HUCL T, GALLMEIER E, KERN SE: Distinguishing rational from irrational applications of pharmacogenetic synergies from the bench to clinical trials. Cell Cycle 6: 1336-1341, 2007.

ISHIAI M, KITAO H, SMOGORZEWSKA A, TOMIDA J, KINOMURA A, UCHIDA E, SABERI A, KINOSHITA E, KINOSHITA-KIKUTA E, KOIKE T, TASHIRO S, ELLEDGE SJ, TAKATA M: FANCI phosphorylation functions as a molecular switch to turn on the Fanconi anemia pathway. Nat Struct Mol Biol 15: 1138-1146, 2008.

JONES S, HRUBAN RH, KAMIYAMA M, BORGES M, ZHANG X, PARSONS DW, LIN JC, PALMISANO E, BRUNE K, JAFFEE EM, IACOBUZIO-DONAHUE CA, MAITRA A, PARMIGIANI G, KERN SE, VELCULESCU VE, KINZLER KW, VOGELSTEIN B, ESHLEMAN JR, GOGGINS M, KLEIN AP: Exomic sequencing identifies PALB2 as a pancreatic cancer susceptibility gene. Science 324: 217, 2009.

KAELIN WG: The concept of synthetic lethality in the context of anticancer therapy. Nature Rev Cancer 5: 689-698, 2005.

KALB R, DUERR M, WAGNER M, HERTERICH S, GROSS M, DIGWEED M, JOENJE H, HOEHN H, SCHINDLER D: Lack of sensitivity of primary Fanconi's anemia fibroblast to UV and ionizing radiation. Radiat Res 161: 318-325, 2004.

KENNEDY RD, D'ANDREA AD: DNA repair pathway in clinical practice: lessons from pediatric cancer susceptibility syndromes. J Clin Oncol 24: 3799-3808, 2006.

KENNEDY RD, CHEN CC, STUCKERT P, ARCHILA EM, DE LA VEGA MA, MOREAU LA, SHIMAURA A, D'ANDREA AD: Fanconi anemia pathway-deficient tumor cells are hypersensitive to inhibition of ataxia telangiectasia mutated. J Clin Invest 117: 1440-1449, 2007. 
KING MC, MARKS JH, MANDELL JB: Breast and ovarian cancer risks due to inherited mutations in BRCA1 and BRCA2. Science 302: 643-646, 2003.

KNIPSCHEER P, RASCHLE M, SMOGORZEWSKA A, ENOIU M, HO TV, SCHARER OD, ELLEDGE SJ, WALTER JC: The Fanconi anemia pathway promotes replication-dependent DNA interstrand cross-link repair. Science 326: 1698-1701, 2009.

KONSTANTINOPOULOS PA, SPENTZOS D, KARLAN BY, TANIGUCHI T, FOUNTZILAS E, FRANCOEUR N, LEVINE DA, CANNISTRA SA: Gene expression profile of BRCAness that correlates with responsiveness to chemotherapy and with outcome in patients with epithelial ovarian cancer. J Clin Oncol 28: 3555-3561, 2010.

LEHMANN AR: Translesion synthesis in mammalian cells. Exp Cell Res 12: 2673-2676, 2006.

LEVITUS M, WAISISZ Q, GODTHELP BC, DE VRIES Y, HUSSAIN S, WIEGANT WW, ELGHALBZOURIMAGHRANI E, STELTENPOOL J, ROOIMANS MA, PALS G, ARWERT F, MATHEW CG, ZDZIENICKA MZ, HIOM K, DE WINTER JP, JOENJE H: The DNA helicase BRIP1 is defective in Fanconi anemia complementation group J. Nat Genet 37: 934-935, 2005.

LINDAHL T, WOOD RD: Quality control by DNA repair. Science 286: 1897-1905, 1999.

LIU T, GHOSAL G, YUAN J, CHEN J, HUANG J: FAN1 acts with FANCI-FANCD2 to promote DNA interstrand cross-link repair. Science 329: 693-696, 2010.

LODISH H: DNA replication, repair, and recombination. In: Molecular Cell Biology. LODISH H, BERK A, ZIPURSKY SL, MATSUDAIRA P, BALTIMORE D, DARNELL JE (eds), W.H.Freeman and Company, New York, 2000, pp 453-494.

MARSIT CJ, LIU M, NELSON JJ, POSNER M, SUZUKI M, KELSEY KT. Inactivation of the Fanconi anemia/BRCA pathway in lung and oral cancers: implications for treatment and survival. Oncogene 23: 1000-1004, 2004.

MCMANUS KJ, BARRETT IJ, NOUHI Y, HIETER P: Specific synthetic lethal killing of RAD54B-deficient human colorectal cancer cells by FEN1 silencing. Proc Natl Acad Sci U S A 106: 3276-3281, 2009.

MIRCHANDANI KD, MCCAFFREY RM, D'ANDREA AD: The Fanconi anemia core complex is required for efficient point mutagenesis and Rev1 foci assembly. DNA Repair (Amst) 7: 902-911, 2008.

MOLDOVAN GL, D'ANDREA AD: How the Fanconi anemia pathway guards the genome. Annu Rev Genet 43: 223249, 2009.

MUKHOPADHYAY A, ALATTAR A, CERBINSKAITE A, WILKINSON SJ, DREW Y, KYLE S, LOS G, HOSTOMSKY Z, EDMONDSON RJ, CURTIN NJ: Development of a functional assay for homologous recombination status in primary cultures of epithelial ovarian tumor and correlation with sensitivity to poly(ADP-ribose) polymerase inhibitors. Clin Cancer Res 16: 2344-2351, 2010.

MURPHY KM, BRUNE KA, GRIFFIN N, SOLLENBERGER JE, PETERSEN GM, BANSAL R, HRUBAN RH, KERN SE: Evaluation of candidate genes MAP2K4, MADH4, ACVR1B, and BRCA2 in familial pancreatic cancer: deleterious BRCA2 mutations in 17\%. Cancer Res 62: 3789-3793, 2002.

NACCARATI A, PARDINI B, HEMMINKI K, VODICKA P: Sporadic colorectal cancer and individual susceptibility: a review of the association studies investigating the role of DNA repair genetic polymorphisms. Mutat Res 635: 118-145, 2007.

NARAYAN G, ARIAS-PULIDO H, NANDULA SV, BASSO K, SUGIRTHARAJ DD, VARGAS H, MANSUKHANI M, VILLELLA J, MEYER L, SCHNEIDER A, GISSMANN L, DURST M, POTHURI B, MURTY VV: Promoter hypermethylation of FANCF: disruption of Fanconi anemia-BRCA pathway in cervical cancer. Cancer Res 64: 2994-2997, 2004.

O'DRISCOLL M, RUIZ-PEREZ VL, WOODS CG, JEGGO PA, GOODSHIP JA: A splicing mutation affecting expression of ataxia-telangiectasia and Rad3-related protein (ATR) results in Seckel syndrome. Nat Genet 33: 497-501, 2003.

PALAGYI A, NEVELING K, PLINNINGER U, ZIESCH A, TARGOSZ BS, DENK GU, OCHS S, RIZZANI A, MEIER D, THASLER WE, HANENBERG H, DE TONI EN, BASSERMANN F, SCHAFER C, GOKE B, SCHINDLER D, GALLMEIER E: Genetic inactivation of the Fanconi anemia gene FANCC identified in the hepatocellular carcinom a cell line HuH-7 confers sensitivity towards DNA-interstrand crossliniking agents. Mol Cancer 9: 127, 2010. 
PEJOVIC T, YATES JE, LIU HY, HAYS LE, AKKARI Y, TORIMARU Y, KEEBLE W, RATHBUN RK, RODGERS WH, BALE AE, AMAZIANE N, ZWAAN CM, ERRAMI A, THUILLIER P, CAPPUCCINI F, OLSON SB, CAIN JM, BAGBY GC Jr: Cytogenetic instability in ovarian epithelial cells from women at risk of ovarian cancer. Cancer Res 66: 9017-9025, 2006.

RAHMAN N, SEAL S, THOMPSON D, KELLY P, RENWICK A, ELLIOTT A, REID S, SPANOVA K, BARFOOT R, CHAGTAI T, JAYATILAKE H, MCGUFFOG L, HANKS S, EVANS DG, ECCLES D, BREAST CANCER SUSCEPTIBILITY COLLABORATION, EASTON DF, STRATTON MR: PALB2, which encodes a BRCA2-interacting protein, is a breast cancer susceptibility gene. Nat Genet 39: 165-167, 2007.

REID S, SCHINDLER D, HANENBERG H, BARKER K, HANKS S, KALB R, NEVELING K, KELLY P, SEAL S, FREUND M, WURM M, BATISH SD, LACH FP, YETGIN S, NEITZEL H, ARIFFIN H, TISCHKOWITZ M, MATHEW CG, AUERBACH AD, RAHMAN N: Biallelic mutations in PALB2 cause Fanconi anemia subtype FA-N and predispose to childhood cancer. Nat Genet 39: 162-164, 2007.

ROTHFUSS A, GROMPE M: Repair kinetics of genomic interstrand DNA cross-links: evidence for DNA doublestrand break-dependent activation of the Fanconi anemia/BRCA pathway. Mol Cell Biol 24: 123-134, 2004.

SEAL S, THOMPSON D, RENWICK A, ELLIOTT A, KELLY P, BARFOOT R, CHAGTAI T, JAYATILAKE H, AHMED M, SPANOVA K, NORTH B, MCGUFFOG L, EVANS DG, ECCLES D; BREAST CANCER SUSCEPTIBILITY COLLABORATION (UK), EASTON DF, STRATTON MF, RAHMAN N: Truncating mutations in the Fanconi anemia J gene BRIP1 are low-penetrance breast cancer susceptibility alleles. Nat Genet 38: 1239-1241, 2006.

SIMON JA, SZANKASI P, NGUYEN DK, LUDLOW C, DUNSTAN HM, ROBERTS CJ, JENSEN EL, HARTWELL LH, FRIEND SH: Differentiall toxicities of anticancer agents among DNA repair and checkpoint mutants of Saccharomyces cerevisiae. Cancer Res 60: 71-83, 1999.

STOEPKER C, HAIN K, SCHUSTER B, HILHORST-HOFSTEE Y, ROOIMANS MA, STELTENPOOL J, OOSTRA $\mathrm{AB}$, EIRICH K, KORTHOF ET, NIEUWINT AW, JASPERS NG, BETTECKEN T, JOENJE H, SCHINDLER D, ROUSE J, DE WINTER JP: SLX4, a coordinator of structure-specific endonucleases, is mutated in a new Fanconi anemia subtype. Nat Genet 43: 138-141, 2011.

TANIGUCHI T, D’ANDREA AD: Molecular pathogenesis of Fanconi anemia: recent progress. Blood 107: 4223-4233, 2006.

TANIGUCHI T, TISCHKOWITZ M, AMEZIANE N, HODGSON SV, MATHEW CG, JOENJE H, MOK SC, D'ANDREA AD: Disruption of the Fanconi anemia-BRCA pathway in cisplatin-sensitive ovarian tumors. Nat Med 9: 568-574, 2003.

TISCHKOWITZ MD, SABBAGHIAN N, HAMEL N, BORGIDA A, ROSNER C, TAHERIAN N, SRIVASTAVA A, HOLTER S, ROTHENMUND H, GHADIRIAN P, FOULES WD, GALLINGER: Analysis of the gene coding for the BRCA2-interacting protein PALB2 in familial and sporadic pancreatic cancer. Gastroenterology 137: 1183-1186, 2009.

TORRANCE CJ, AGRAWAL V, VOGELSTEIN B, KINZLER KW: Use of isogenic human cancer cells for highthroughput screening and drug discovery. Nat Biotechnol 19: 940-945, 2001.

TUTT A, BERTWISTLE D, VALENTINE J, GABRIEL A, SWIFT S, ROSS G, GRIFFIN C, THACKER J, ASHWORTH A: Mutation in BRCA2 stimulates error-prone homology-directed repair of DNA double-strand breaks occurring between repeated sequences. EMBO J 20: 4704-4716, 2001.

VAN DER HEIJDEN MS, BRODY JR, GALLMEIER E, CUNNINGHAM SC, DEZENTJE DA, SHEN D, HRUBAN RH, KERN SE: Functional defects in the fanconi anemia pathway in pancreatic cancer cells. Am J Pathol 165: 651-657, 2004.

VAN DER HEIJDEN MS, YEO CJ, HRUBAN RH, KERN SE: Fanconi anemia gene mutations in young-onset pancreatic cancer. Cancer Res 63: 2585-2588, 2003.

VAN HAAFTEN G, VASTENHOUW NL, NOLLEN EAA, PLASTERK RHA, TIJSTERMAN M: Gene interactions in the DNA damage-response pathway identified by genome-wide RNA-interference analysis of synthetic lethality. Proc Natl Acad Sci U S A 101: 12992-12996, 2004.

VELAZQUEZ I, ALTER BP: Androgens and liver tumors: Fanconi's anemia and non-Fanconi's conditions. Am $J$ Hematol 77: 257-267, 2004. 
VOGELSTEIN B, KIZLER KW: Cancer gees ad the pathways they control. Nat Med 10: 789-799, 2004.

WILLINGHAM AT, DEVERAUX QL, HAMPTON GM, AZA-BLANC P: RNAi and HTS: exploring cancer by systematic loss-of-function. Oncogene 23: 8392-8400, 2004.

XIA B, DORSMAN JC, AMEZIANE N, DE VRIES Y, ROOIMANS MA, SHENG Q, PALS G, ERRAMI A, GLUCKMAN E, LLERA J, WANG W, LIVINGSTON DM, JOENJE H, DE WINTER JP: Fanconi anemia is associated with a defect in the BRCA2 partner PALB2. Nat Genet 39: 159-161, 2007.

XIE Y, DE WINTER JP, WAISFISZ Q, NIEUWINT AW, SCHEPER RJ, ARWERT F, HOATLIN ME, OSSENKOPPELE GJ, SCHUURHUIS GJ, JOENJE H: Aberrant Fanconi Anaemia protein profiles in acute myeloid leukamia cells. Br J Haematol 111: 1057-1064, 2000.

YANG H, JEFFREY PD, MILLER J, KINNUCAN E, SUN Y, THOMA NH, ZHENG N, CHEN PL, LEE WH, PAVLETICH NP: BRCA2 function in DNA binding and recombination from a BRCA2-DSS1-ssDNA structure. Science 297: 1837-1848, 2002.

ZHENG H, WANG X, WARREN AJ, LEGERSKI RJ, NAIRN RS, HAMILTON JW, LI L: Nucleotide excision repairand polymerase $\eta$-mediated error-prone removal of mitomycin C interstand cross-links. Mol Cell Biol 23: 754$761,2003$. 